\title{
AN APPLICATION OF FUZZY LOGIC TO ASSESS SERVICE QUALITY ATTRIBUTES IN LOGISTICS INDUSTRY
}

\author{
Ahmad Esmaeili ${ }^{1}$, Reza Ahmadi Kahnali ${ }^{2}$, Reza Rostamzadeh ${ }^{3}$, \\ Edmundas Kazimieras Zavadskas ${ }^{4}$, Babak Ghoddami ${ }^{5}$ \\ ${ }^{1,5}$ Dept of Industrial Management, Allameh Tabataba'i University, Tehran, Iran \\ ${ }^{2}$ Dept of Management, Hormozgan University, Bandar Abbas, Iran \\ ${ }^{3}$ Dept of Management, Urmia Branch, Islamic Azad University, Urmia, Iran \\ ${ }^{4}$ Research Institute of Smart Building Technologies, \\ Vilnius Gediminas Technical University, Vilnius, Lithuania
}

Submitted 5 October 2014; resubmitted 16 February 2015; accepted 17 February 2015

\begin{abstract}
Differentiation, growing competitive advantage, and excellence has been proved to be the result of service quality. At the same time, measuring attributes of service quality and customer satisfaction is fuzzy and ambiguous, and methods available for their measurement are generally classical. This paper proposes a fuzzy method to identify the service quality attributes. This approach was developed using crisp assessment methods in a logistics company. Applying the proposed fuzzy approach, service quality attributes and indicators are identified and then organized into 8 categories, to see the uncertainty level of each. The proposed method was successfully conducted in a real logistics company. The results show the membership degree of each indicator, suggesting customer expectations regarding quality. Also, the membership degrees of the service quality attributes suggest the ability of each to describe service quality in logistics industry.
\end{abstract}

Keywords: fuzzy sets theory; fuzzy entropy; service quality; quality attributes; logistics.

\section{Introduction}

Progressive economies are dominantly becoming more service alerted and the growing share of the service sector is evident in all aspects (McKee 2008; Ramsey, Bond 2007). No one can neglect the vital role of the service sector and service related issues in growing economies and for the growth of the countries. This is due to the fact that the manufacturing sector is growing more similar to the service sector, not to mention the fact that around $80 \%$ of the United States Gross Domestic Product (GDP) is related to services (Gunasekaran, Ngai 2004). As a matter of fact, the share of services in GDP is growing in all nations around the world. Therefore, effective implementation of evaluation instruments would help organisations in the service sector to meet the market needs and, specifically, customer expectations. In this regard, this study focuses on the quality of logistics services, which is the basis of logistics enterprises. Also, the level of service quality supplied by those companies determines customer satisfaction; therefore, resulting in their competitive advantage. This is conceded by Bow- ersox et al. $(1991,1995)$ stating that to develop an effective tool for building close relationships between a firm and its customers, leveraging a firm's logistics service capability is a critical issue. Logistics companies provide services for various enterprises that are affected by the quality of that logistics service. Thus, the improvement of logistics service quality must be a continuous focus for logistics service providers (Stank et al. 1999). Nonetheless, researchers and practitioners have never reached common ground in defining the concept of quality in terms of logistics service and the related attributes and metrics. However so far, several researchers have investigated this subject and their conclusions and proposals in relation to the evaluation of service quality in logistics are largely different in terms of attributes. It also seems that there has been very little research in logistics services, on how its quality is defined and attributed in terms of attributes and metrics. Also, geographical differences and different national policies have determined the emergence of local types of logistics providers. Hence, this paper aims at addressing gaps in the literature by a

Corresponding author: Ahmad Esmaeili

E-mails: esmaeili921@atu.ac.ir; ahmet.ismaeili@gmail.com 
detailed review of dimensions pertaining to the quality of logistics services. In addition, the paper proposes and validates an assessment method of service quality attributes through fuzzy logic evaluation for practical management of customs-related logistics services. For this purpose, empirical data was collected from an Iranian customs and logistics company.

The rest of the paper is structured as follows: the methodology of service quality attributes extracted from the literature and the review of fuzzy sets and membership functions are introduced in section 1. To enhance real case issues, an analysis of the reviewed method in the logistics service sector, which is believed to represent attributes of service quality in logistics is given in section 2. Ultimately, a summary of the contributions of the paper is presented in last section.

\section{Literature Review}

\subsection{Logistics Service Quality}

Logistics services generally include unloading, warehousing and loading of goods. Such services are required inside and outside organisations. This paper considers customs logistics services: unloading, warehousing and loading of imported and exported goods by various manufacturing companies in the analysed geographical area. First, relevant literature on logistics services and specific dimensions of logistics service quality is reviewed to give an account of the definition of service quality and expand its various aspects focusing on the proposed methodology.

Over the past decades, most of service quality literature was dedicated to the development of reliable and applicable assessment tools to measure the concept. Among the assessment tools, perhaps the most renowned and the most commonly used is the SERVQUAL scale (Ladhari 2009). The SERVQUAL is basically used in 5 service areas - credit card services, retail banking, longdistance telephone services, title brokerage, and repair and maintenance of electrical appliances - which consist of 5 attributes and are represented by 22 items. This scale is used as a tool for service quality assessment under various service conditions. Ladhari (2009) indicated that despite the criticisms against SERVQUAL, it is a useful tool for the assessment of service quality. He also suggested that to determine the structure of service quality in various sectors, researchers must develop a relative assessment tool based on SERVQUAL and extract the implicit attributes of service quality accordingly. Additionally, most researches indicated that constant evaluation of customer expectations and needs with different methods helps companies to retain current customers and attract new ones as well as reduces costs and increases efficiency (Júnior et al. 2008; Zhu et al. 2011). The review of the relevant literature (Franceschini, Rafele 2000; Mentzer et al. 2001; Bottani, Rizzi 2006; Karpuzcu 2006; So et al. 2006; Júnior et al. 2008; Taskin, Durmaz 2010; Kamble et al. 2011; Kilibarda et al. 2012; Ho et al. 2012; Thai 2013) revealed attributes that have been studied in relation to the quality of logistics services. We identified the attributes appropriate for this particular industry. Literature that is related to this area mainly focuses on the functional attributes of service quality and ignores its technical aspects (Carman 1990; Cronin, Taylor 1992; Akroush 2009). Besides, this study attempts to identify the most emerging service quality attributes in the logistics industry to broaden the service quality evaluation scale as suggested by Ladhari (2009). Most of the studies (Bottani, Rizzi 2006; Karpuzcu 2006; So et al. 2006; Kilibarda et al. 2012; Ho et al. 2012; Thai 2013) incorporate fuzzy methods to evaluate the attributes. They have tried to evaluate service quality using expectations and perceptions of customers to prioritize the service quality attributes or service quality indicators and failed to incorporate the fuzzy logic in the first phase of evaluation to conform to real world conditions and overcome the deficiency of human judgment. Baki et al. (2009) conducted a SWOT analysis on a cargo company using SERVQUAL and Kano model aimed at categorizing service quality attributes. The aim of their study was to identify metrics that satisfy customer needs, which was the basis to develop Quality Function Deployment (QFD) method of analysis. Customer needs were prioritized based on QFD analysis and the top 3 quality attributes: VIP Service, informing customers about delivery time before sending, and taking deliveries from customer addresses. Ho et al. (2012) used variables - 'condition/accuracy of order', 'availability/quality of personnel', 'timeliness', and 'quality of information' etc. - to identify the most important attributes in service delivery. The results revealed that customers of courier services ranked 'condition/accuracy of order' as important than 'timeliness'. Thai (2013) aimed to explore the definition of the quality concept in logistics service and associated attributes concerning logistics. Using a survey of logistics providers operating in Singapore, he utilized explanatory factor analysis and proposed a revised model of top 5 attributes (customer focus quality, order fulfilment quality, corporate image, timeliness, and information quality) that included 20 items of logistics service quality. In their study, Tadić et al. (2014) proposed a model that can be used to support decision makers redefining the concept of urban logistics. They developed a new hybrid MCDM model based on fuzzy DEMATEL, fuzzy ANP and fuzzy VIKOR. Entrusted with the selection of a solution for urban logistics, decision makers (users, logistics service providers, city administration, planners etc.) can have a better understanding of the contributing factors. A holistic view can be formed taking into account each decision maker's point of view. Chang (2014) evaluated hospital service quality utilizing fuzzy VIKOR method in Taiwan. The framework of the study was based on fuzzy sets theory and VIKOR method. He included 6 service quality dimensions made from 33 sub-criteria. The results indicated 5 most important criteria for evaluation of hospital service quality based on the developed fuzzy method. Markovits-Somogyi and Bokor (2014) studied the efficiency of logistics in European countries by using the DEA-PC (pairwise comparison) method- 
ology. Through the use of non-parametric linear programming method combined with the analytic hierarchy process, they assessed the efficiency of decision making units in the transport sector. Also, the results of the assessment process were evaluated according to the index of Logistics Performance Indicator (LPI), to assess them based on the most recent survey conducted in European countries. What comes next is an overview of studies in logistics service quality, which is briefly presented in Table 1, and according to which the most emerging attributes of logistics were identified to shape this study's assessment model in logistics service quality.

\subsection{Service Quality Evaluation}

A questionnaire consisting of 39 items driven from literature review in logistics service quality was used to assess each metric based on five-point scale. All respondents expressed their judgments on the following questions:

- What is the level of services the company delivers?

- What should be the level of services the company delivers?

It is important to determine the service quality attributes of the company, based on the perceptions and

Table 1 . Summary of the most cited literature on logistics service quality

\begin{tabular}{|c|c|c|c|}
\hline Author/s (year) & Study type & Data analysis & Final attributes \\
\hline $\begin{array}{l}\text { Mentzer et al. } \\
\text { (1989) }\end{array}$ & $\begin{array}{l}\text { Service quality } \\
\text { outcomes }\end{array}$ & - & Availability, timeliness and quality \\
\hline $\begin{array}{l}\text { Mentzer et al. } \\
(1999)\end{array}$ & $\begin{array}{l}\text { Third party logistics } \\
\text { service evaluation }\end{array}$ & - & $\begin{array}{l}\text { Personnel contact quality, order release quantities, information } \\
\text { quality, ordering procedures, order accuracy, order condition, } \\
\text { order quality, order discrepancy handling and timeliness }\end{array}$ \\
\hline $\begin{array}{l}\text { Franceschini, } \\
\text { Rafele (2000) }\end{array}$ & $\begin{array}{l}\text { Logistic quality } \\
\text { indicators }\end{array}$ & Literature review & $\begin{array}{l}\text { Lead time, regularity, reliability, completeness, flexibility, } \\
\text { correctness, harmfulness, productivity }\end{array}$ \\
\hline $\begin{array}{l}\text { Mentzer et al. } \\
(2001)\end{array}$ & Logistics service quality & $\begin{array}{l}\text { Using SPSS and } \\
\text { K2 test }\end{array}$ & $\begin{array}{l}\text { Personnel contact quality, order release quantities, information } \\
\text { quality, ordering procedures, order accuracy, order condition, } \\
\text { order quality, order discrepancy handling, timeliness }\end{array}$ \\
\hline So et al. (2006) & Logistics service quality & $\begin{array}{l}\text { Analytical } \\
\text { Hierarchical } \\
\text { Process }\end{array}$ & Reliability, assurance, tangibles, empathy, responsiveness \\
\hline $\begin{array}{l}\text { Bottani, Rizzi } \\
(2006)\end{array}$ & $\begin{array}{l}\text { Logistics service } \\
\text { management }\end{array}$ & QFD, HOQ, FAHP & $\begin{array}{l}\text { Lead-time, regularity, reliability, completeness, flexibility, } \\
\text { correctness, harmfulness, productivity }\end{array}$ \\
\hline $\begin{array}{l}\text { Karpuzcu } \\
(2006)\end{array}$ & Logistics service quality & $\begin{array}{l}\text { Analytical } \\
\text { Hierarchical } \\
\text { Process }\end{array}$ & $\begin{array}{l}\text { Reliability, assurance, tangibles, empathy, responsiveness, } \\
\text { availability }\end{array}$ \\
\hline $\begin{array}{l}\text { Chan et al. } \\
(2006)\end{array}$ & Logistics evaluation & $\begin{array}{l}\text { Analytical } \\
\text { Hierarchical } \\
\text { Process }\end{array}$ & $\begin{array}{l}\text { Reliability, lead time, convenience, flexibility, cost, return on } \\
\text { assets, relationship }\end{array}$ \\
\hline $\begin{array}{l}\text { Jamaludin } \\
(2006)\end{array}$ & $\begin{array}{l}\text { Quality evaluation of a } \\
\text { company }\end{array}$ & $\begin{array}{l}\text { SWOT to identify } \\
\text { CSFs }\end{array}$ & $\begin{array}{l}\text { Performance, features, reliability, conformance, technical } \\
\text { durability, serviceability, aesthetics, perceived quality, } \\
\text { humanity, value }\end{array}$ \\
\hline $\begin{array}{l}\text { Aguezzoul } \\
(2007)\end{array}$ & $\begin{array}{l}\text { Evaluation of logistics } \\
\text { companies }\end{array}$ & Literature review & $\begin{array}{l}\text { Price, reliability, service quality, on-time performance, cost } \\
\text { reduction, flexibility and innovation, good communication, } \\
\text { speed of service }\end{array}$ \\
\hline $\begin{array}{l}\text { Júnior et al. } \\
(2008)\end{array}$ & $\begin{array}{l}\text { Evaluation of logistics } \\
\text { services (case study) }\end{array}$ & - & Support, reliability, performance, availability \\
\hline $\begin{array}{l}\text { Taskin, } \\
\text { Durmaz (2010) }\end{array}$ & $\begin{array}{l}\text { Logistics in creating } \\
\text { customer value }\end{array}$ & $\begin{array}{l}\text { Multivariate } \\
\text { Analysis }\end{array}$ & Reliability, assurance, tangibles, empathy, responsiveness \\
\hline $\begin{array}{l}\text { Banomyong, } \\
\text { Supatn (2011) }\end{array}$ & $\begin{array}{l}\text { Selecting appropriate } \\
\text { provider }\end{array}$ & Regression & Reliability, responsiveness, assurance, empathy, tangibility, cost \\
\hline $\begin{array}{l}\text { Kamble et al. } \\
(2011)\end{array}$ & $\begin{array}{l}\text { validating a construct } \\
\text { and measurement } \\
\text { instrument for Logistics } \\
\text { Service Quality (LSQ) }\end{array}$ & $\begin{array}{l}\text { Confirmatory } \\
\text { Factor Analysis }\end{array}$ & $\begin{array}{l}\text { Information quality, ordering procedures, order release } \\
\text { quantities, timeliness, order accuracy, order quality, order } \\
\text { condition, order discrepancy handling and personal contact } \\
\text { quality }\end{array}$ \\
\hline Ho et al. (2012) & $\begin{array}{l}\text { determining the most } \\
\text { effective attribute }\end{array}$ & $\begin{array}{l}\text { Multiple regression } \\
\text { analysis }\end{array}$ & $\begin{array}{l}\text { Timeliness, condition/accuracy of order, quality of } \\
\text { information, and availability/quality of personnel }\end{array}$ \\
\hline $\begin{array}{l}\text { Kilibarda et al. } \\
(2012)\end{array}$ & $\begin{array}{l}\text { Designing a model for } \\
\text { evaluation of logistics } \\
\text { service quality }\end{array}$ & $\begin{array}{l}\text { Analytical } \\
\text { Hierarchical } \\
\text { Process }\end{array}$ & $\begin{array}{l}\text { The completeness of the logistic service, reliability of the } \\
\text { logistic service, time required for delivery of goods, frequency } \\
\text { of delivery, delivery benefit and damaged goods }\end{array}$ \\
\hline Thai (2013) & - & $\begin{array}{l}\text { Inferential Statistics } \\
\text { (t-test) }\end{array}$ & $\begin{array}{l}\text { Customer focus quality, order fulfilment quality, corporate } \\
\text { image, timeliness and information quality }\end{array}$ \\
\hline
\end{tabular}


expectations of customers. However, one should remember that all respondents express their opinion according to on-hand data while the decision-making process is vague and unknown. The opinion of respondents about the definition of a single concept is his/her own and may vary in the means of scores. Any decision is based on the information and the subjectivity of a concept can add to its vagueness, and in the objective terms might be considered as lack of information (Dubois, Prade 2013). To show the uncertainty of assessments in service quality evaluation by respondents, with the aid of a fuzzy membership function, we tried to fuzzify the crisp results of the questionnaires. This approach allows varying degrees of memberships in a single set of numbers. The construction of a membership function requires the consideration of semantics (interpretation) of a function, and the proper method for that semantics should be chosen accordingly.

The construction of fuzzy belongingness functions have been studied by numerous authors. According to the literature, three distinct methods can be summarized (Soyer et al. 2007):

- subjective evaluation and elicitation methods: approaches that include subjective judgments rather that real data in the issue (Huber 1974; Dubois, Prade 1997):

- measurement-theoretic approaches (Bilgiç, Türkşen 1995; Crowther et al. 1995);

- intuition-based approaches (Liu et al. 2007);

- probabilistic approaches (Baas, Kwakernaak 1977);

- heuristic methods, parameterized functions, in which standard shapes are used for belongingness functions (Jang 1993; Choi, Rhee 2009);

- estimation methods using synthetic and real data sets (Medasani et al. 1998):

- neural network techniques (Kosko 1991; Detienne et al. 2003).

- fuzzy clustering methods (Hall et al. 1992; Bezdek, Pal 1992).

- curve fitting methods (Klir, Yuan 1995; Roychowdhury 1998).

The selection of the proper method is related to the data gathered and various types of the problem (Jang 1993; Medasani et al. 1998; Choi, Rhee 2009). Also, there is no precise measure to evaluate the generated membership function in terms of correctness and goodness (Huber 1974; Dubois, Prade 1997; Medasani et al. 1998).

The values are crisp and based on the attributes and metrics of the literature; thus, we should maintain the original features of the metrics. For this reason and with the focus on the nature of the problem, an S-shaped membership function is utilized. With the help of expert judgments, all associated parameters are enhanced with the membership function.

Eq. (1) represents the membership function $\mu_{v(\bar{x} i)}$ generated for service quality metrics. The average of judgments of the item $i$ given by all respondents is represented by $\bar{x}_{i}$ (Fig. 1). For example, if $\bar{x}_{i}$ is greater than 4 , we can conclude that the metric indicates the

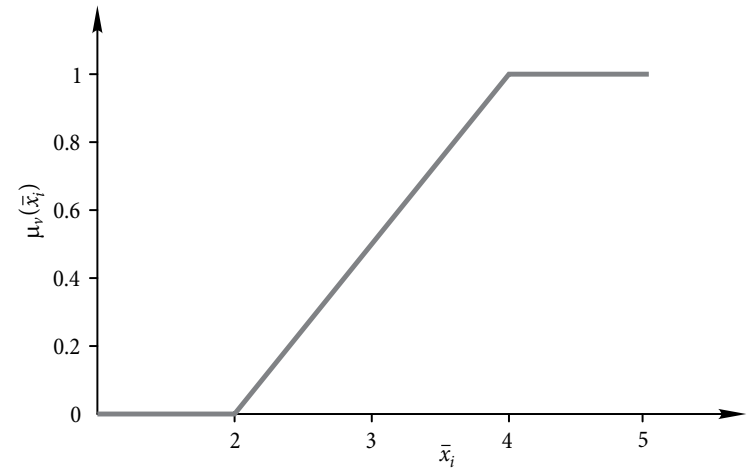

Fig. 1. Membership function of service quality metrics

service quality in the company. Furthermore, it can be inferred that the membership value is 1. Accordingly, if it is smaller than 2, it is clear that the metric shows the service quality in the company and the membership value is 0 . Besides, it is assumed that there exists a linear membership function between 2 and 4 . In the end it can be concluded that the membership value conveys that a metric either shows the service quality in logistics or not as well as the current and desired value of the metrics. Then, using the functions, values are fuzzified:

$$
\mu_{v(\bar{x})}= \begin{cases}0, & \text { if } \bar{X}<2 ; \\ \frac{\bar{X}-2}{2}, & \text { if } 2 \leq \bar{X} \leq 4 ; \\ 1, & \text { if } \bar{X}>4 .\end{cases}
$$

\subsection{Evaluation of Attributes in Crisp Environment}

Based on the service quality evaluation literature reviewed by the authors, the service quality attributes require modification in every industry and on the basis of 5 generic attributes of SERVQUAL, basically defined by Parasuraman et al. (1985) and then improved by Parasuraman et al. (1991, 1994). According to Parasuraman et al. (1985), the service quality assessment by customers is a result of the mismatch between their expectations and what is really delivered based on ten attributes:
1) tangibles;
2) reliability;
3) responsiveness;
4) communication;
5) credibility;
6) security;
7) competence;
8) courtesy;
9) understanding/knowing customers;
10) access.

The final edition of the SERVQUAL scale categorized the 10 attributes mentioned above into 5 generic attributes, namely (Parasuraman et al. 1991, 1994):
1) tangibles;
2) reliability;
3) responsiveness;
4) assurance;
5) empathy. 
In a review, Ladhari (2009) suggests that to determine the structure of service quality in various sectors, researchers must develop the relative assessment tool based on the SERVQUAL and extract the implicit attributes of service quality accordingly. Therefore, based on the evaluation of logistics service quality, 3 more attributes are added to meet the industry need:

6) timeliness: the time between service request and delivery of the service;

7) availability: availability of staff, Processes, facilities in needed time;

8) flexibility: the capability of staff and the company to conform to unpredictable changes and the flexibility of processes.

All the attributes and metrics for each of the attributes are listed in Table 2.
The attributions of service quality in logistics industry are recognized through existence (degree of belongingness) of relevant metrics. According to the proposed method, if the membership was complete in the set, then it can be argued that it is a member in the crisp set. Also, the results are analysed based on the level of decision to consider the gradual membership of all of the metrics enhanced by the application of the fuzzy approach. Therefore, to distinguish the possible service quality indicators and service quality attributes, 3 levels (average, high, very high) have been assigned. Table 3 gives the corresponding numbers of items for each level and service quality attributes. For instance, the service quality attribute, 'availability' consists of four metrics (AVA1, AVA2, AVA3, AVA4), and in order to state 'the company's services can be assessed using avail-

Table 2. Service quality attributes and metrics

\begin{tabular}{|c|c|}
\hline Service Quality Attributes & Metrics \\
\hline \multirow{6}{*}{ Tangibles } & TAN1: Modern-looking equipment \\
\hline & TAN2: Staffs appears neat \\
\hline & TAN3: The organisation has modern facilities \\
\hline & TAN4: Easy transportation ways inside the organisation \\
\hline & TAN5: Enough IT services inside the organisation. \\
\hline & TAN6: Enough convenient spaces inside the organisation for rest \\
\hline \multirow{4}{*}{ Timeliness } & TIM1: Adequate customer response time \\
\hline & TIM2: Convenient processing time \\
\hline & TIM3: Timeliness according to what organisation promises \\
\hline & TIM4: Short time between placing requisition and receiving delivery \\
\hline \multirow{4}{*}{ Availability } & AVA1: Difficulties never occur due to minimum release quantities \\
\hline & AVA2: Service processes are adequate and easy to use \\
\hline & AVA3: Service processes are always accessible for customers \\
\hline & AVA4: Difficulties never occur due to maximum release quantities \\
\hline \multirow{5}{*}{ Reliability } & REL1: When the organisation promises to do something, it does it \\
\hline & REL2: The organisation performs the service right the first time \\
\hline & REL3: When you have problems, customs show a genuine interest in solving them \\
\hline & REL4: Customs provide their services at the time it promise to do so \\
\hline & REL5: Customs insist on error-free service \\
\hline \multirow{5}{*}{ Flexibility } & FLE1: Flexibility and ease in order placement procedures \\
\hline & FLE2: Response to requests are treated flexibly \\
\hline & FLE3: Flexibility and ease in payment methods \\
\hline & FLE4: The report on discrepancy process is adequate \\
\hline & FLE5: Staff are flexible enough to take the initiative in emergency situations \\
\hline \multirow{4}{*}{ Assurance } & ASS1: The behaviour of staff instils confidence in you \\
\hline & ASS2: Staff of the customs is consistently courteous with you \\
\hline & ASS3: You feel safe in the delivery of service \\
\hline & ASS4: Response to quality discrepancy reports is satisfactory \\
\hline \multirow{5}{*}{ Empathy } & EMP1: The organisation gives you individual attention \\
\hline & EMP2: The staff gives your personal attention \\
\hline & EMP3: The staff understands your specific needs \\
\hline & EMP4: The staff has the knowledge to answer your question \\
\hline & EMP5: Convenient open hours to all its clients \\
\hline \multirow{6}{*}{ Responsiveness } & RES1: Staff tells you exactly when services will be performed \\
\hline & RES2: Staff gives your prompt service \\
\hline & RES3: Staff is never too busy to respond to your request \\
\hline & RES4: Delivery of orders regardless of amount \\
\hline & RES5: Responding to unexpected/urgent orders \\
\hline & RES6: Willingness to help customers \\
\hline
\end{tabular}


Table 3. Numbers of items for each decision level and service quality attribute

\begin{tabular}{lllccc}
\hline \multirow{2}{*}{$\begin{array}{c}\text { Service quality } \\
\text { attributes }\end{array}$} & \multicolumn{1}{c}{ Item set } & Total number of items & \multicolumn{3}{c}{ Attribute decision levels } \\
\cline { 3 - 7 } Tangibles & TAN1, TAN2, TAN3, TAN4, TAN5, TAN6 & 6 & Average & High & Very high \\
\hline Timeliness & TIM1, TIM2, TIM3, TIM4 & 4 & 3 & 4 & 5 \\
\hline Availability & AVA1, AVA2, AVA3, AVA4 & 4 & 2 & 3 & 4 \\
\hline Reliability & REL1, REL2, REL3, REL4, REL5 & 5 & 3 & 4 & 5 \\
\hline Flexibility & FLE1, FLE2, FLE3, FLE4, FLE5 & 5 & 3 & 4 & 5 \\
\hline Assurance & ASS1, ASS2, ASS3, ASS4 & 4 & 2 & 3 & 4 \\
\hline Empathy & EMP1, EMP2, EMP3, EMP4, EMP5 & 5 & 3 & 4 & 5 \\
\hline Responsiveness & RES1, RES2, RES3, RES4, RES5, RES6 & 6 & 3 & 4 & 5 \\
\hline
\end{tabular}

ability attribute at the average level' the results should be identified as having any two of these metrics at higher level of quality.

The fuzzy membership of the metrics means that attributes also have fuzzy features. The transformation of metrics membership degrees to logistics service quality attributes was done using a method extracted from the intersection of fuzzy sets. For the first time, Zadeh (1965) extended intersection to fuzzy sets.

According to Soyer et al. (2007), all functions of a given notion are described as the maximum of the minimum membership degrees in the compounds. Using mathematics, the formula is as follows:

$$
\mu_{C-L}(\bar{X})=\sup _{r 1, \ldots, r n \in S}\left\{\Lambda_{k=l}^{n} \mu_{v}\left(\bar{x}_{r k}\right)\right\},
$$

where: $C-L$ shows the service quality attributes and $C S$ shows the attribute set; $n$ is the representation of the number of metrics that should exist for a given attribute and attribute level; $\bar{x}$ is a vector of all average values of responses.

More importantly, a concept that needs to be addressed in the assessment is uncertainty. There exist various measures for uncertainty quantification. Pal (1999) declares that three types of uncertainty are evident in the research agenda. According to him, those three groups include: fuzziness, non-specificity and randomness. As service quality attributes are said to have different priorities in various times and settings, and their memberships alter through time and conditions, only an uncertainty resulting from fuzziness is interesting and proper for this study (Klir, Yuan 1995).

Several famous metrics of fuzziness exist in the literature (Pal 1999; Zadeh 1968; Pal, Bezdek 1994). The evaluation of fuzziness for a given set is $H: P_{x}(X) \rightarrow R^{+}$, in which the degree of fuzziness in numbers is the result. According to De Luca and Termini (1972) axioms, Ebanks (1983) maintained that following properties must be satisfied by a fuzziness measure:

Sharpness $P 1: H(A)=0 \leftrightarrow \mu_{A}(x)=0$ or $1, \forall_{x} \in X$; Maximality $P 2: H(A)$ is maximum $\leftrightarrow \mu_{A}(x)=0.5$, $\forall_{x} \in X$;

Resolution P3: $H(A) \geq H\left(A^{*}\right)$, where $A^{*}$ is a sharpened version of $A$;
Symmetry $P 4: H(A)=H(\bar{A})$,

where $\mu_{\bar{A}}(x)=1-\mu_{A}(x), \forall \forall_{x} \in X$;

Valuation $P 5: H(A \cup B)+H(A \cap B)=H(A)+H(B)$.

Shang and Jiang (1997) developed a measure that satisfies the above mentioned properties:

$$
H(C)=\frac{1}{n} \sum_{t-1}^{n} \frac{\mu_{C} \cap_{C}\left(\bar{X}_{i}\right)}{\mu_{\bar{C}}\left(\bar{X}_{i}\right)},
$$

where: $n$ represents the number of metrics in a attribute; $\bar{x}$ is regarded as average of judgments for each of metrics; $i$ and $\bar{\mu}_{C}(\bar{x})$ represents the degree of belongingness of metric $i$ to the attribute set $C$. Also, the complement set of $C$ is $\bar{C}$. Fig. 2 depicts the structure of the methodology for service quality metrics.

\section{Application}

\subsection{Implementation of Indicator Assessment}

For the evaluation of service quality indicators in logistics industry, the initial step was to collect data through a questionnaire from customers of the company. The sample consisted of the customers of the company. Due to the reason that customers are limited, a number of traders were added to the population. 19 customers were included in the study. After collecting the data to calculate the belongingness degree though use of Eq. (1), the mean of the responses was taken. The current level of service quality is assessed and e.g. the mean of responses the REL5, $\bar{X}_{i}$, is equal to 4.33 and through the use of Eq. (1) the belongingness degree was determined:

$$
\mu_{v}(4.33)=\frac{(4.33-2)}{2}=1 \text {. }
$$

According to the results given in Table 4, TIM2, TIM4, REL5, ASS2 and RES5 are the strongest indicators in terms of the current level of service quality; i.e., the company completely holds these indicators at this level. The company can also be said to have TIM1, TIM2, TIM3, TIM4, AVA1, AVA3, REL1, REL2, REL4, REL5, FLE3, FLE5, ASS2, ASS3, EMP1,EMP2, EMP3, RES1, RES2, RES5, and RES6 due to the reason that these metrics represent moderately strong belongingness degrees $(>80 \%)$. 


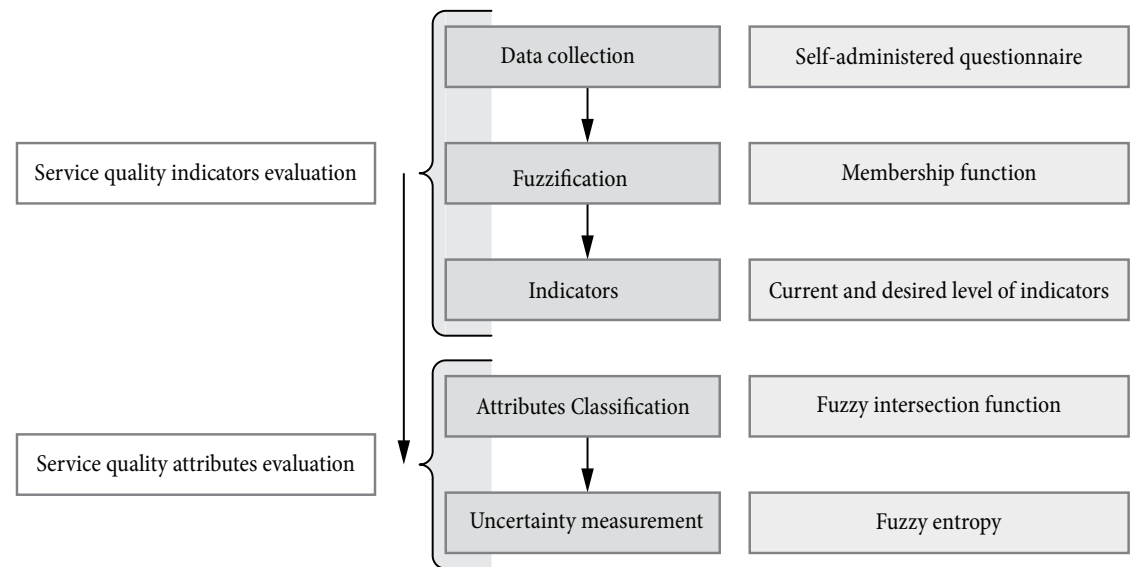

Fig 2. Fuzzy-based methodology for evaluation of service quality attributes and quality indicators

A summary of the results is presented in Table 4. As shown in the results, all those metrics that represent strong belongingness degrees can better explain the service quality level in the logistics industry.

The desired level of the indicators having the highest level of membership shows that in all indicators, customers expect the highest level of service quality. This expectation forces the company to adapt all of the indicators.

\subsection{Implementation of Attribute Assessment}

With the implementation of Eq. (2), the belongingness degrees of service quality attributes are computed as shown in Table 5. Furthermore, the fuzzy entropy measures for each attribute are represented in Table 5 through the use of Eq. (3). The computation of the belongingness degree of one of the attributes at the middle level is given below as an example:

$\mu_{C-L}^{(\bar{x})}=\sup _{r_{1}, \ldots, r_{3} \in c s}\left\{\Lambda_{2}^{k=1}\left(\bar{X}_{r k}\right)\right\}=$

$\sup \{\Lambda(1,2), \Lambda(1,3), \Lambda(1,4), \Lambda(2,3), \Lambda(2,4), \Lambda(3,4)\}=$ $\sup \{\Lambda(0.84,1), \Lambda(0.84,0.84), \Lambda(0.84,1), \Lambda(1,0.84), \Lambda(1,1), \Lambda(0.84,1)\}=$ $\sup \{0.84,0.84,1\}=1$.

The result of the calculation suggests that at the middle level, the company shows the attributes of 'Timeliness' with the belongingness degree of 1 .

Also, Table 5 shows that based on the decision level 'High' the results indicate that the attributes: 'Timeliness' and 'Responsiveness' score the highest among other attributes, which is in accordance with the results of Franceschini and Rafele (2000) study. Here, the attribute 'Responsiveness' with a membership degree of 0.9 shows that this attribute describes the service quality better than other attributes, and 'Timeliness' attribute ranks second in the ability to describe the service quality with a membership degree of 0.84 . Also, other attributes show relatively high degree of membership ( $>0.7)$, 'availability, flexibility, assurance and empathy' had membership degree of ' $0.74,0.7,0.77,0.77$ ', which indicates that a lower degree can describe service quality too. As an example, the calculation of one of the attributes 'Timeliness' is presented below:

$$
\begin{aligned}
& H(\text { Timelines })=\frac{1}{4}\left(\frac{\min \left\{\mu\left(x_{1}\right) ; 1-\mu\left(x_{1}\right)\right\}}{\max \left\{\mu\left(x_{1}\right) ; 1-\mu\left(x_{1}\right)\right\}}+\right. \\
& \frac{\min \left\{\mu\left(x_{2}\right) ; 1-\mu\left(x_{2}\right)\right\}}{\max \left\{\mu\left(x_{2}\right) ; 1-\mu\left(x_{2}\right)\right\}}+\frac{\min \left\{\mu\left(x_{3}\right) ; 1-\mu\left(x_{3}\right)\right\}}{\max \left\{\mu\left(x_{3}\right) ; 1-\mu\left(x_{3}\right)\right\}}+ \\
& \frac{\min \left\{\mu\left(x_{4}\right) ; 1-\mu\left(x_{4}\right)\right\}}{\max \left\{\mu\left(x_{4}\right) ; 1-\mu\left(x_{4}\right)\right\}}+\frac{\min \left\{\mu\left(x_{5}\right) ; 1-\mu\left(x_{5}\right)\right\}}{\max \left\{\mu\left(x_{5}\right) ; 1-\mu\left(x_{5}\right)\right\}}+ \\
& \left.\frac{\min \left\{\mu\left(x_{6}\right) ; 1-\mu\left(x_{6}\right)\right\}}{\max \left\{\mu\left(x_{6}\right) ; 1-\mu\left(x_{6}\right)\right\}}\right) \\
& H(\text { Timelines })=\frac{1}{4}\left(\frac{\min \{0.84 ; 0.16\}}{\max \{0.84 ; 0.16\}}+\right. \\
& \left.\frac{\min \{1 ; 0\}}{\max \{1 ; 0\}}+\frac{\min \{0.84 ; 016\}}{\max \{0.84 ; 0.16\}}+\frac{\min \{1 ; 0\}}{\max \{1 ; 0\}}\right) \text {; } \\
& H(\text { Timelines })=\frac{1}{4}\left(\frac{0.16}{0.84}+\frac{0}{1}+\frac{0.16}{0.84}+\frac{0}{1}\right) \text {; } \\
& \mathrm{H}(\text { Timelines })=\frac{1}{4}(0.19+0+0.19+0) \text {; } \\
& \mathrm{H}(\text { Timelines })=\frac{0.38}{4}=0.09 \text {. }
\end{aligned}
$$

'Middle' level or 'average' level of decision shows relatively similar outcomes with respect to 'high' decision level. Moving from 'high' level to 'very high' level, 'Timeliness' and 'Responsiveness' attributes are dominant still.

Fuzzy entropy with the chance of containing more accurate results is taken into account in this process. With respect to the results given in Table 4 the most uncertain attribute with the result of $51 \%$ is 'Flexibility'. This shows a lower degree of certainty in the service quality assessment. In other words, it shows a poor understanding of the service quality in the logistics industry. 
Table 4. Results of the questionnaire and belongingness degree of the current and the desired level of service quality

\begin{tabular}{|c|c|c|c|c|c|}
\hline \multirow{2}{*}{ Indicator } & \multirow[t]{2}{*}{$i$} & \multicolumn{2}{|c|}{$\begin{array}{l}\text { Current level of } \\
\text { indicators }\end{array}$} & \multicolumn{2}{|c|}{$\begin{array}{l}\text { Desired level of } \\
\text { indicators }\end{array}$} \\
\hline & & $\bar{x}_{i}$ & $\mu_{v}\left(\bar{x}_{i}\right)$ & $\bar{y}_{i}$ & $\mu_{v}\left(\bar{y}_{i}\right)$ \\
\hline TAN1 & 1 & 3.47 & 0.74 & 4.60 & 1 \\
\hline TAN2 & 2 & 3.13 & 0.57 & 4.87 & 1 \\
\hline TAN3 & 3 & 3.33 & 0.67 & 4.67 & 1 \\
\hline TAN4 & 4 & 3.33 & 0.67 & 4.53 & 1 \\
\hline TAN5 & 5 & 3.00 & 0.50 & 447 & 1 \\
\hline TAN6 & 6 & 2.20 & 0.10 & 4.53 & 1 \\
\hline TIM1 & 7 & 3.67 & 0.84 & 4.73 & 1 \\
\hline TIM2 & 8 & 4.07 & 1.00 & 4.73 & 1 \\
\hline TIM3 & 9 & 3.67 & 0.84 & 4.73 & 1 \\
\hline TIM4 & 10 & 4.13 & 1.00 & 4.80 & 1 \\
\hline AVA1 & 11 & 3.87 & 0.94 & 4.73 & 1 \\
\hline AVA2 & 12 & 3.20 & 0.60 & 4.66 & 1 \\
\hline AVA3 & 13 & 3.80 & 0.90 & 4.47 & 1 \\
\hline AVA4 & 14 & 3.47 & 0.74 & 4.67 & 1 \\
\hline REL1 & 15 & 3.80 & 0.90 & 4.67 & 1 \\
\hline REL2 & 16 & 3.86 & 0.93 & 4.80 & 1 \\
\hline REL3 & 17 & 3.20 & 0.60 & 4.60 & 1 \\
\hline REL4 & 18 & 3.80 & 0.90 & 4.73 & 1 \\
\hline REL5 & 19 & 4.33 & 1.00 & 4.60 & 1 \\
\hline FLE1 & 20 & 3.40 & 0.70 & 4.53 & 1 \\
\hline FLE2 & 21 & 3.53 & 0.77 & 4.53 & 1 \\
\hline FLE3 & 22 & 3.73 & 0.87 & 4.87 & 1 \\
\hline FLE4 & 23 & 3.13 & 0.57 & 4.53 & 1 \\
\hline FLE5 & 24 & 3.67 & 0.84 & 4.67 & 1 \\
\hline ASS1 & 25 & 3.20 & 0.60 & 4.67 & 1 \\
\hline ASS2 & 26 & 4.20 & 1.00 & 4.60 & 1 \\
\hline ASS3 & 27 & 3.73 & 0.87 & 4.67 & 1 \\
\hline ASS4 & 28 & 3.53 & 0.77 & 4.80 & 1 \\
\hline EMP1 & 29 & 3.80 & 0.90 & 4.73 & 1 \\
\hline EMP2 & 30 & 3.80 & 0.90 & 4.73 & 1 \\
\hline EMP3 & 31 & 3.60 & 0.80 & 4.53 & 1 \\
\hline EMP4 & 32 & 3.53 & 0.77 & 4.60 & 1 \\
\hline EMP5 & 33 & 3.33 & 0.67 & 4.33 & 1 \\
\hline RES1 & 34 & 3.87 & 0.94 & 4.73 & 1 \\
\hline RES2 & 35 & 3.93 & 0.97 & 4.67 & 1 \\
\hline RES3 & 36 & 3.60 & 0.80 & 4.67 & 1 \\
\hline RES4 & 37 & 3.40 & 0.70 & 4.60 & 1 \\
\hline RES5 & 38 & 4.27 & 1.00 & 4.60 & 1 \\
\hline RES6 & 39 & 3.80 & 0.90 & 4.67 & 1 \\
\hline
\end{tabular}

Notes: $i$ - number of metrics in each attribute; $\bar{x}_{i}$ - mean of all responses for the metric $i$ in the current level of service quality; $\mu_{v}\left(\bar{x}_{i}\right)$ - membership degree of value $i$ in the current level of service quality; $\bar{y}_{i}$ - average of responses for value $i$ in the expected level of service quality; $\mu_{v}\left(\bar{y}_{i}\right)$ - membership degree of value $i$ in the expected level of service quality.
Table 5. Membership degree and fuzzy entropy measures of service quality attributes in logistics industry

\begin{tabular}{lcccc}
\hline \multirow{2}{*}{ Attributes } & \multirow{2}{*}{$\begin{array}{c}\text { Fuzzy } \\
\text { entropy }\end{array}$} & \multicolumn{3}{c}{$\begin{array}{c}\text { Service quality attributes } \\
\text { decision levels }\end{array}$} \\
\cline { 2 - 5 } Tangibles & 0.45 & 0.65 & 0.57 & 0.50 \\
\hline Timeliness & 0.09 & 1 & 0.84 & 0.84 \\
\hline Availability & 0.30 & 0.9 & 0.74 & 0.60 \\
\hline Reliability & 0.19 & 0.9 & 0.6 & 0.6 \\
\hline Flexibility & 0.51 & 0.77 & 0.7 & 0.57 \\
\hline Assurance & 0.28 & 0.87 & 0.77 & 0.6 \\
\hline Empathy & 0.25 & 0.8 & 0.77 & 0.67 \\
\hline Responsiveness & 0.15 & 0.94 & 0.9 & 0.8 \\
\hline
\end{tabular}

Also, it shows an indecision of customers with respect to these attributes. In this context, 'Flexibility' and 'Tangibles' are the most uncertain attributes of service quality in the logistics industry.

On the other hand, 'Timeliness' and 'Responsiveness' have the lowest degree of fuzziness, namely, 0.09 and 0.15 , which support their high membership degrees. Consequently, we can conclude that 'Timeliness, Responsiveness and Reliability' can be the best attributes to describe service quality in logistics industry.

\section{Conclusions}

The aim of this research was to validate the attributes of service quality in an un-researched area of services in order to better contribute to customer satisfaction. Service quality improvements can solve many problems. In this study, we tried to propose a fuzzy method to assess service quality attributes. The suggested methodology is applied for the customs warehousing company and its logistics services. Although many researches have investigated the service quality in logistics industry, none provide an accurate assessment of the attributes, which are capable of describing service quality best. Also, some attributes are inherent in every industry and context regarding service assessment as mentioned by Ladhari (2009). The vagueness of judgments about service quality can be added to the complexity of the problem. To conquer the defects mentioned before, we aimed to suggest a methodology to show the capability of fuzzy theories in the analysis of service quality attributes. It should be noted that in crisp evaluation, an attribute of a concept would not be the member of assessment unless it gains a complete belongingness degree, but the suggested method considers gradual belongingness degree of the attributes, allowing a full and more accurate assessment. More importantly, this method proposes different decision levels for the belongingness of an attribute that exhibits even the level of uncertainty, making the process more accurate and sensible to understand.

At the end, to address a real world case in the chosen industry, the method was utilized to assess a customs warehousing company in Iran. However, with 
slight changes it is also applicable to various logistics companies working in the industry. The insistence on the fact that these attributes should be applied only in the same industry comes from the literature review and the definition of service quality that must be clarified in case of each industry. All inherent attributes must be classified according to the industry and then evaluation indicators have to be developed.

Within the proposed approach, one can have a comparison of the service quality attributes and metrics, which has been proven to be more consistent than traditional statistical methods.

Future scope of this research can be expansion of the reviewed literature and at the same time collect data based on subjective perceptions of the customers. This allows for a better understanding of the fuzzy data and omits the process of fuzzifying data. Also, different new methods of belongingness generation can add to the richness of future studies.

\section{Acknowledgements}

The authors would like to deeply thank the Deputy of Research and Technology of Hormozgan University (Iran) for the generous support.

\section{References}

Aguezzoul, A. 2007. The third party logistics selection: a review of literature, in International Logistics and Supply Chain Congress, 8-9 November 2007, Istanbul, Turkey, 1-7.

Akroush, M. N. 2009. Does service quality implementation mediate the relationship between technical service quality and performance: an empirical examination of banks in Jordan, International Journal of Services, Economics and Management 1(3): 209-232.

http://dx.doi.org/10.1504/IJSEM.2009.022964

Baas, S. M.; Kwakernaak, H. 1977. Rating and ranking of multiple-aspect alternatives using fuzzy sets, Automatica 13(1): 47-58. http://dx.doi.org/10.1016/0005-1098(77)90008-5

Baki, B.; Basfirinci, C. S.; Murat, I.; Cilingir, Z. 2009. An application of integrating SERVQUAL and Kano's model into QFD for logistics services: a case study from Turkey, Asia Pacific Journal of Marketing and Logistics 21(1): 106-126. http://dx.doi.org/10.1108/13555850910926272

Banomyong, R.; Supatn, N. 2011. Selecting logistics providers in Thailand: a shippers' perspective, European Journal of Marketing 45(3): 419-437.

http://dx.doi.org/10.1108/03090561111107258

Bezdek, J. C.; Pal, S. K. 1992. Fuzzy Models for Pattern Recognition: Methods that Search for Structures in Data. IEEE Press. 544 p.

Bilgiç, T.; Türkşen, İ. B. 1995. Measurement-theoretic justification of connectives in fuzzy set theory, Fuzzy Sets and Systems 76(3): 289-307.

http://dx.doi.org/10.1016/0165-0114(95)00067-4

Bottani, E.; Rizzi, A. 2006. Strategic management of logistics service: a fuzzy QFD approach, International Journal of Production Economics 103(2): 585-599. http://dx.doi.org/10.1016/j.ijpe.2005.11.006

Bowersox, D. J.; Daugherty, P. J.; Dröge, C. L.; Germain, R. N.; Rogers, D. S. 1991. Logistical Excellence: it's not Business as Usual. Digital Press. 260 p.
Bowersox, D. J.; Mentzer, J. T.; Speh, T. W. 1995. Logistics leverage, Journal of Business Strategies 12(2): 36-49.

Carman, J. M. 1990. Consumer perceptions of service quality: An assessment of the SERVQUAL dimensions, Journal of Retailing 66(1): 33-55.

Chan, F. T. S.; Chan, H. K.; Lau, H. C. W.; Ip, R. W. L. 2006. An AHP approach in benchmarking logistics performance of the postal industry, Benchmarking: An International Journal 13(6): 636-661. http://dx.doi.org/10.1108/14635770610709031

Chang, T.-H. 2014. Fuzzy VIKOR method: a case study of the hospital service evaluation in Taiwan, Information Sciences 271: 196-212. http://dx.doi.org/10.1016/j.ins.2014.02.118

Choi, B.-I.; Rhee, F. C.-H. 2009. Interval type-2 fuzzy membership function generation methods for pattern recognition, Information Sciences 179(13): 2102-2122.

http://dx.doi.org/10.1016/j.ins.2008.04.009

Cronin, J. J.; Taylor, S. A. 1992. Measuring service quality: a reexamination and extension, Journal of Marketing 56(3): 55-68. http://dx.doi.org/10.2307/1252296

Crowther, C. S.; Batchelder, W. H.; Hu, X. 1995. A measurement-theoretic analysis of the fuzzy logic model of perception, Psychological Review 102(2): 396-408. http://dx.doi.org/10.1037/0033-295X.102.2.396

De Luca, A.; Termini, S. 1972. A definition of a nonprobabilistic entropy in the setting of fuzzy sets theory, Information and Control 20(4): 301-312. http://dx.doi.org/10.1016/S0019-9958(72)90199-4

Detienne, K. B.; Detienne, D. H.; Joshi, S. A. 2003. Neural networks as statistical tools for business researchers, Organizational Research Methods 6(2): 236-265. http://dx.doi.org/10.1177/1094428103251907

Dubois, D.; Prade, H. 2013. Possibility Theory: an Approach to Computerized Processing of Uncertainty. Springer. $280 \mathrm{p}$.

Dubois, D.; Prade, H. 1997. The three semantics of fuzzy sets, Fuzzy Sets and Systems 90(2): 141-150. http://dx.doi.org/10.1016/S0165-0114(97)00080-8

Ebanks, B. R. 1983. On measures of fuzziness and their representations, Journal of Mathematical Analysis and Applications 94(1): 24-37. http://dx.doi.org/10.1016/0022-247X(83)90003-3

Franceschini, F.; Rafele, C. 2000. Quality evaluation in logistic services, International Journal of Agile Management Systems 2(1): 49-54. http://dx.doi.org/10.1108/14654650010312589

Gunasekaran, A.; Ngai, E. W. T. 2004. Information systems in supply chain integration and management, European Journal of Operational Research 159(2): 269-295. http://dx.doi.org/10.1016/j.ejor.2003.08.016

Hall, L. O.; Bensaid, A. M.; Clarke, L. P.; Velthuizen, R. P.; Silbiger, M. S.; Bezdek, J. C. 1992. A comparison of neural network and fuzzy clustering techniques in segmenting magnetic resonance images of the brain, IEEE Transactions on Neural Networks 3(5): 672-682. http://dx.doi.org/10.1109/72.159057

Ho, J. S. Y.; Teik, D. O. L.; Tiffany, F.; Kok, L. F.; The, T. Y. 2012. Logistic service quality among courier services in Malaysia, International Proceedings of Economics Development \& Research (IPEDR) 38: 113-117.

Huber, G. P. 1974. Methods for quantifying subjective probabilities and multi-attribute utilities, Decision Sciences 5(3): 430-458. http://dx.doi.org/10.1111/j.1540-5915.1974.tb00630.x

Jamaludin, K. R.; Abdul Talib, H. H.; Hooi, T. C. 2006. Overal Performance Measurement for Logistics Operations: Monogpaph. University of Technology, Malaysia. 152 p. 
Jang, J.-S. R. 1993. ANFIS: adaptive-network-based fuzzy inference system, IEEE Transactions on Systems, Man and Cybernetics 23(3): 665-685. http://dx.doi.org/10.1109/21.256541

Júnior, J. I. V.; Souki, G. Q.; Filho, C. G. 2008. Logistic service quality evaluation: an empirical case study from the pharmaceutical sector, Revista de Administração da Universidade Federal de Santa Maria - Brazilian Journal of Management 1(2): 209-224.

Kamble, S. S.; Raut, R. D.; Dhume, S. M. 2011. Validating the logistics service quality (LSQ) scale in Indian logistics industry, in 2010 International Conference on Business and Economics Research, 26-28 November 2010, Kuala Lumpur, Malaysia, 1: 81-85.

Karpuzcu, H. 2006. Measuring Service Quality in Distribution Logistics Using SERVQUAL and AHP: A Case Study in a Pharmaceutical Wholesaler in Turkey: A dissertation presented in part consideration for the degree of "MSc Operations Management". University of Nottingham.

Kilibarda, M.; Zečević, S.; Vidović, M. 2012. Measuring the quality of logistic service as an element of the logistics provider offering, Total Quality Management \& Business Excellence 23(11-12): 1345-1361.

http://dx.doi.org/10.1080/14783363.2012.704279

Klir, G. J.; Yuan, B. 1995. Fuzzy Sets and Fuzzy Logic: Theory and Applications. Prentice Hall. 592 p.

Kosko, B. 1991. Neural Networks and Fuzzy Systems: a Dynamical Systems Approach to Machine Intelligence. Prentice Hall. 449 p.

Ladhari, R. 2009. A review of twenty years of SERVQUAL research, International Journal of Quality and Service Sciences 1(2): 172-198.

http://dx.doi.org/10.1108/17566690910971445 .

Liu, X.; Wang, W.; Chai, T.; Liu, W. 2007. Approaches to the representations and logic operations of fuzzy concepts in the framework of axiomatic fuzzy set theory II, Information Sciences 177(4): 1027-1045.

http://dx.doi.org/10.1016/j.ins.2006.07.012

Markovits-Somogyi, R.; Bokor, Z. 2014. Assessing the logistics efficiency of European countries by using the DEA-PC methodology, Transport 29(2): 137-145.

http://dx.doi.org/10.3846/16484142.2014.928787

McKee, D. L. 2008. Services, growth poles and advanced economies, Service Business 2(2): 99-107.

http://dx.doi.org/10.1007/s11628-007-0026-y

Medasani, S.; Kim, J.; Krishnapuram, R. 1998. An overview of membership function generation techniques for pattern recognition, International Journal of Approximate Reasoning 19(3-4): 391-417.

http://dx.doi.org/10.1016/S0888-613X(98)10017-8

Mentzer, J. T.; Flint, D. J.; Hult, T. M. 2001. Logistics service quality as a segment-customized process, Journal of Marketing 65(4): 82-104.

http://dx.doi.org/10.1509/jmkg.65.4.82.18390

Mentzer, J. T.; Flint, D. J.; Kent, J. 1999. Developing a logistics service quality scale, Journal of Business Logistics 20(1): 9-32.

Mentzer, J. T.; Gomes, R.; Krapfel, R. E. 1989. Physical distribution service: A fundamental marketing concept?, Journal of the Academy of Marketing Science 17(1): 53-62. http://dx.doi.org/10.1007/BF02726354

Pal, N. R. 1999. On quantification of different facets of uncertainty, Fuzzy Sets and Systems 107(1): 81-91. http://dx.doi.org/10.1016/S0165-0114(98)00005-0

Pal, N. R.; Bezdek, J. C. 1994. Measuring fuzzy uncertainty, IEEE Transactions on Fuzzy Systems 2(2): 107-118. http://dx.doi.org/10.1109/91.277960
Parasuraman, A.; Berry, L. L.; Zeithaml, V. A. 1991. Refinement and reassessment of the SERVQUAL scale, Journal of Retailing 67(4): 420-450.

Parasuraman, A.; Zeithaml, V. A.; Berry, L. L. 1994. Alternative scales for measuring service quality: A comparative assessment based on psychometric and diagnostic criteria, Journal of Retailing 70(3): 201-230.

http://dx.doi.org/10.1016/0022-4359(94)90033-7

Parasuraman, A.; Zeithaml, V. A.; Berry, L. L. 1985. A conceptual model of service quality and its implications for future research, Journal of Marketing 49(4): 41-50.

http://dx.doi.org/10.2307/1251430

Ramsey, E.; Bond, D. 2007. Evaluating public policy formation and support mechanisms for technological innovation, International Review of Applied Economics 21(3): 403-418. http://dx.doi.org/10.1080/02692170701390387

Roychowdhury, S. 1998. Fuzzy curve fitting using least square principles, in 1998 IEEE International Conference on Systems, Man, and Cybernetics, 11-14 October 1998, San Diego, CA, 4: 4022-4027. http://dx.doi.org/10.1109/ICSMC.1998.726718

Shang, X.-G.; Jiang, W.-S. 1997. A note on fuzzy information measures, Pattern Recognition Letters 18(5): 425-432. http://dx.doi.org/10.1016/S0167-8655(97)00028-7

So, S.-H.; Kim, J. J.; Cheong, K. J.; Cho, G. 2006. evaluating the service quality of thirdparty logistics service providers using the Analytic Hierarchy Process, Journal of Information Systems and Technology Management 3(3): 261-270. http://dx.doi.org/10.4301/S1807-17752006000300001

Soyer, A.; Kabak, Ö.; Asan, U. 2007. A fuzzy approach to value and culture assessment and an application, International Journal of Approximate Reasoning 44(2): 182-196. http://dx.doi.org/10.1016/j.ijar.2006.07.008

Stank, T. P.; Goldsby, T.; Vickery, S. K. 1999. Effect of service supplier performance on satisfaction and loyalty of store managers in the fast food industry, Journal of Operations Management 17(4): 429-447. http://dx.doi.org/10.1016/S0272-6963(98)00052-7

Tadić, S.; Zečević, S.; Krstić, M. 2014. A novel hybrid MCDM model based on fuzzy DEMATEL, fuzzy ANP and fuzzy VIKOR for city logistics concept selection, Expert Systems with Applications 41(18): 8112-8128. http://dx.doi.org/10.1016/j.eswa.2014.07.021

Taskin, E.; Durmaz, Y. 2010. The role of service quality of the logistic activities in creating customer value and a research on the institutional customers of Yurtici cargo, European Journal of Economics, Finance and Administrative Sciences (23): 170-178.

Thai, V. V. 2013. Logistics service quality: conceptual model and empirical evidence, International Journal of Logistics Research and Applications 16(2): 114-131. http://dx.doi.org/10.1080/13675567.2013.804907

Zadeh, L. A. 1968. Probability measures of fuzzy events, Journal of Mathematical Analysis and Applications 23(2): 421427. http://dx.doi.org/10.1016/0022-247X(68)90078-4

Zadeh, L. A. 1965. Fuzzy sets, Information and Control 8(3): 338353. http://dx.doi.org/10.1016/S0019-9958(65)90241-X

Zhu, J. C.; Ramanathan, R.; Ramanathan, U. 2011. Measuring Service Quality using SERVQUAL and AHP: an application to a Chinese IT company and comparison, International Journal of Services and Operations Management 8(4): 418-432. http://dx.doi.org/10.1504/IJSOM.2011.039662 